\title{
State of restructuring and development trends
}

\author{
Murodhujaeva Feruza Majidovna ${ }^{1}$ \\ ${ }^{1}$ Namangan State University Senior Lecturer, Department of Economics, Namangan, Republic \\ of Uzbekistan \\ Email:feruza_m@umail.uz
}

\begin{abstract}
The content of the restructuring process in the regions is presented in economic, social and organizational terms, and the methodological approaches to its definition are revealed. Factors determining the peculiarities of the restructuring in the regions were identified, the systematized indicators of the financial and economic condition and the order of its implementation were described. Organizational and economic problems of restructuring were revealed in the regions and measures for their solution were identified.

Keywords: Region, enterprise restructuring, structural changes, the project of restructuring, the factors of restructuring, operational restructuring, strategic restructuring, emerging risk factors in the restructuring process.
\end{abstract}

\section{INTRODUCTION}

The effectiveness of structural transformations in the context of globalization processes and economic transformations in the context of a deepening competition environment largely depends on their regional organization.

This can be seen on the example of restructuring of separate industries.

The prevailing view of restructuring in the economic literature at the level of industry or individual enterprise (companies) can be explained by the following:

$\checkmark$ High level of integration of the economic system in developed countries in the sectoral and regional context;

$\checkmark$ in countries such as the United States, Canada, Russia, and Brazil, although there is a territorial dispersion (which in the US and Canada experience can be interpreted as the regional economic independence), these countries are in the form of a federal organizational structure;

$\checkmark$ The processes of restructuring have been studied in the economic literature on the example of large companies and corporations, and these companies are transnational;

$\checkmark$ The restructuring of regional economies is often carried out at the sectoral level. This can be explained by the example of the restructuring of the East German economy ("New Federal Lands") implemented in Germany in the 1990s.

It is therefore advisable to consider in this study the processes of restructuring regional economies as an example of industrial production, which is central to the economic system.

Before analyzing the financial and economic situation of industrial enterprises of Namangan region, it is necessary to briefly describe the socio-economic potential of the region and its role in the distribution of labor in the country.

\section{LITERATURE REVIEW}

The study of restructuring and related processes is reflected in the scientific work of a number of domestic and foreign scientists. Methodological approaches to the problem of restructuring R. Andersen, D. Braun, L. Vodachek, P. Gerhard, A. Alpatov, A. Bachurin, V. Mitskevich, II Mazur, V.D Shapiro, A. Tutundjyan, N. Ekimova, AK Nagoeva [2-7].

In our country, theoretical, methodological and practical aspects of restructuring were carried out by economists GK Saidova, MN Abdullaeva, B. Berkinov, A. Berdikulov [8-11] and others. However, in these studies, the problem is generally treated as a microeconomic category for restructuring and has not been thoroughly researched at the level of dissertation research. To date, the theoretical and methodological 
model of restructuring has not been fully developed and acceptable for practical application. At the same time, the more recent and more universal conceptions of restructuring have been undermined by new research that has not been fully implemented into production, with management requirements or the current level of technology and technology. This work differs from the above studies by identifying the role of restructuring in regional economic growth and enhancing its effectiveness, justifying and improving its regional features and mechanisms.

\section{RESEARCH METHODOLOGY}

Systematic analysis, mathematical and statistical methods, comparisons, grouping, graphs were used during the research.

\section{ANALYSIS AND RESULTS}

Namangan region accounted for $1.7 \%$ of the country in $2018,8.3 \%$ of the country's permanent population, $7.7 \%$ of the employed in the economy, $4.5 \%$ of GDP, $2.5 \%$ of industrial output, $7.3 \%$ of agricultural production. $\%$, investments in fixed assets $-6.6 \%$, foreign investments $-9.0 \%$, construction $4.1 \%$, services $-4.1 \%$, including retail trade $-5.9 \%$, wholesale trade $-3.7 \%$, with $1.7 \%$ of exports and $4.8 \%$ of imports (2018).

In terms of per capita GRP production, the region has relatively high economic growth rates, almost 2 times lower than the national average ( 0.52 for the last 5 years). In particular, the GDP growth rate for the past five years has been $8.7 \%$ on average (7.4\% of the national average), compared to $12.0 \%$ for industrial products and $20.9 \%$ for fixed capital investments. (Annex 1). At the same time, Namangan region is still far below the national average for production of goods, services and investments. In 20132018 , industrial production and gross domestic product per capita in the region were 2.9 times lower than the national average and 1.9 times less than in the attracted investments. The per capita agricultural output was $8.3 \%$ lower than the national average. Light industry $(35.6 \%)$ and foodstuffs $(28.4 \%)$, machinery and metal processing $(6.2 \%)$, construction materials $(4.5 \%)$, energy $(4.5 \%)$ and industry $(4.6 \%)$ are the main sectors of the industry. $4.1 \%)$, forestry and wood processing $(3.4 \%)$. The enterprises with foreign capital are 103 enterprises, which make up $1.9 \%$ of the enterprises of the Republic.

In 2018, the number of industrial enterprises in the region is 4,445, of which only 41 are the largest or $1.1 \%$. At present, $97.1 \%$ of existing industrial enterprises are economic entities.

In addition, $73.1 \%$ of industrial output is produced by local enterprises, and $26.9 \%$ - by stateowned enterprises. In this regard, the regional index is 1.4 times higher than the national average, and is the second largest city in Tashkent after $76.5 \%$. This indicator is, first of all, a high share of consumer goods in industrial production of Namangan region $(69.6 \%$ of total industrial output, 1.8 times higher than the national average, and the second in Andijan region (71.3\%)). Secondly, the regional small business sector has a high share in the sector's production (34.4\%, which is 1.3 times higher than the national average). Thirdly, the high level of private domestic investment and commercial bank loans is high in the regional industrial sector.

Analysis of the data shows that the GRP in the region has a stable growth rate $(8.7 \%$ on average over the next 5 years) and it is closely related to the development of the sectoral structure.

Table 1

Dynamics of GRP Growth and Changes in the Structure of GRP in Namangan Region (in\%)

\begin{tabular}{|c|c|c|c|c|c|c|c|}
\hline Indicators & ฮิ & ฮิণ & ๕ి & ஓి & בิ๊ & 赵 & $\stackrel{\infty}{\stackrel{4}{8}}$ \\
\hline $\begin{array}{l}\text { Gross regional product, bln. } \\
\text { soum }\end{array}$ & 171,6 & 475,7 & 791,4 & 1872,5 & 3759,2 & 7154,0 & 18141,4 \\
\hline Growth rate, in percent & & & 107,7 & 109,9 & 110,0 & 108,7 & 102,5 \\
\hline $\begin{array}{l}\text { Share of basic sectors in } \\
\text { GRP, in percent }\end{array}$ & & & & & & & \\
\hline industrial production & 10,0 & 9,6 & 9,3 & 6,7 & 9,9 & 14,1 & 11,7 \\
\hline construction & 7,2 & 4,2 & 6,8 & 6,4 & 7,5 & 6,0 & 4,8 \\
\hline agriculture & 44,7 & 37,6 & 45,8 & 33,9 & 34,8 & 31,5 & 48,9 \\
\hline
\end{tabular}




\begin{tabular}{|l|c|c|c|c|c|c|c|}
\hline $\begin{array}{l}\text { transportation and } \\
\text { communication }\end{array}$ & 12,6 & 23,3 & 6,8 & 8,6 & 9,3 & 8,6 & 5,8 \\
\hline trade and catering & 8,7 & 7,9 & 8,6 & 8,3 & 9,3 & 9,3 & 7,6 \\
\hline Other & 16,9 & 17,5 & 22,6 & 36,0 & 29,3 & 30,5 & 21,2 \\
\hline
\end{tabular}

* The table is compiled based on data from the Namangan Region Department of Statistics

In contrast to the period before 2012, GDP in 2013-2017 includes gross agricultural output (4.5\% annually, $18.7 \%$ gross), construction $(6.8 \%)$, transport and communications $(3,3)$. The share of trade and public catering increased by almost $10 \%$ year-on-year, and industrial production grew by an average of $7.8 \%$ per year, more than 1.3 times during the five-year review period. It is evident that the share of industry is the highest in ensuring the growth trend of GRP in the region. However, the share of industrial production in the region in GRP decreased by $5.2 \%$ in $2005-2009$, or by $1 \%$ annually. The share of industry in GRP increased by $10.9 \%$ per annum in the post-2009 period, or doubled over the past 8 years.

The regional investment program for the socio-economic development of Namangan region for 2009-2012 is based on these growth processes in the industrial sector, mitigating the negative impact of the global financial and economic crisis that began in 2008 and the government's anti-crisis measures. Industry development program for 2011-2015 and regional programs of industrial production development in the regions played an important role. Implementation of such integrated sectoral and regional programs Decree of the President of the Republic of Uzbekistan dated December 15, 2010 "On Priorities for the Development of Industry of the Republic of Uzbekistan in 2011-2015", April 7, 2014 on March 4, 2015 "Modernization and Diversification of Production for 2015-2019, Ensuring Structural Changes". "On the Program of measures to drink decrees are closely related.

It should be noted that over the past years, the emphasis on the development of agricultural processing sectors, including the light and food industries, which retains a dominant position in GRP, has been instrumental in the effectiveness of the programs.

"Within the regional programs adopted by the Government of the country, great attention is paid to the development of light industry. The program for 2013-2015 envisages production of light industry products with the deep processing of 17 cotton fiber in the region. Some 11,237 new jobs were created.

According to the analysis of the structure of consumer goods production, consumer goods production in the region during 2010-2014 is 2.7 times, including foodstuffs 2.1 times, non-food products 2.7 times, light industry products. and increased by 3.9 times. " 2 .

The growth rates of light industry products for the last 5 years remained stable at an average of $14.1 \%$, while their share in the gross regional product was $38.4 \%$, however, due to the diversification processes in the sector and the shortage of raw materials. the figure dropped from $39 \%$ to $35.7 \%$ in 2013 2016, and in 2017 the share of the industry in the gross regional industry reached $40.0 \%$.

The analysis shows that the level of resource utilization in the light industry of the region is very low. Thus, the region produced almost 76,000 cotton yarn in 2015, 68.5 thousand tons in 2016, and 56.7 thousand tons in 2017, but only 6,100 tons of cotton yarn was produced in 2017 alone. This is only $10.7 \%$ of the 2017 Cotton Fiber. At the same time, according to statistics, it is 4.5 times more than in 2016. In 2017, the production of ready-made silk fabrics was only $84,000 \mathrm{~m} 2$ and increased 3.5 times compared to 2016. At the same time, following the policy of diversification of agricultural production in recent years, cotton production in the region has increased by $25.5 \%$ over the last three years, cotton production by $22.3 \%$, cotton production by $7 \%$. reduced. Accordingly, in recent years the growth rates of light industry in the region have been driven by finished products - yarn, finished knitwear. The Uztex Uchkurgan spinning and knitting company, part of the Uztex company, launched in 2017, specializes in the production of modern cotton and mixed yarn, woolen fabrics and finished products, with a total capacity of 16.5 thousand tons of yarn a year. Production of 7 thousand tons of linen was made. In 2018, the plant will process $38 \%$ of regional cotton fiber.

More than 2000 years in the environment of sustainable macroeconomic growth and economic modernization. 


\section{Share of industrial sectors in GRP of Namangan region, in percent}

Fig 1.

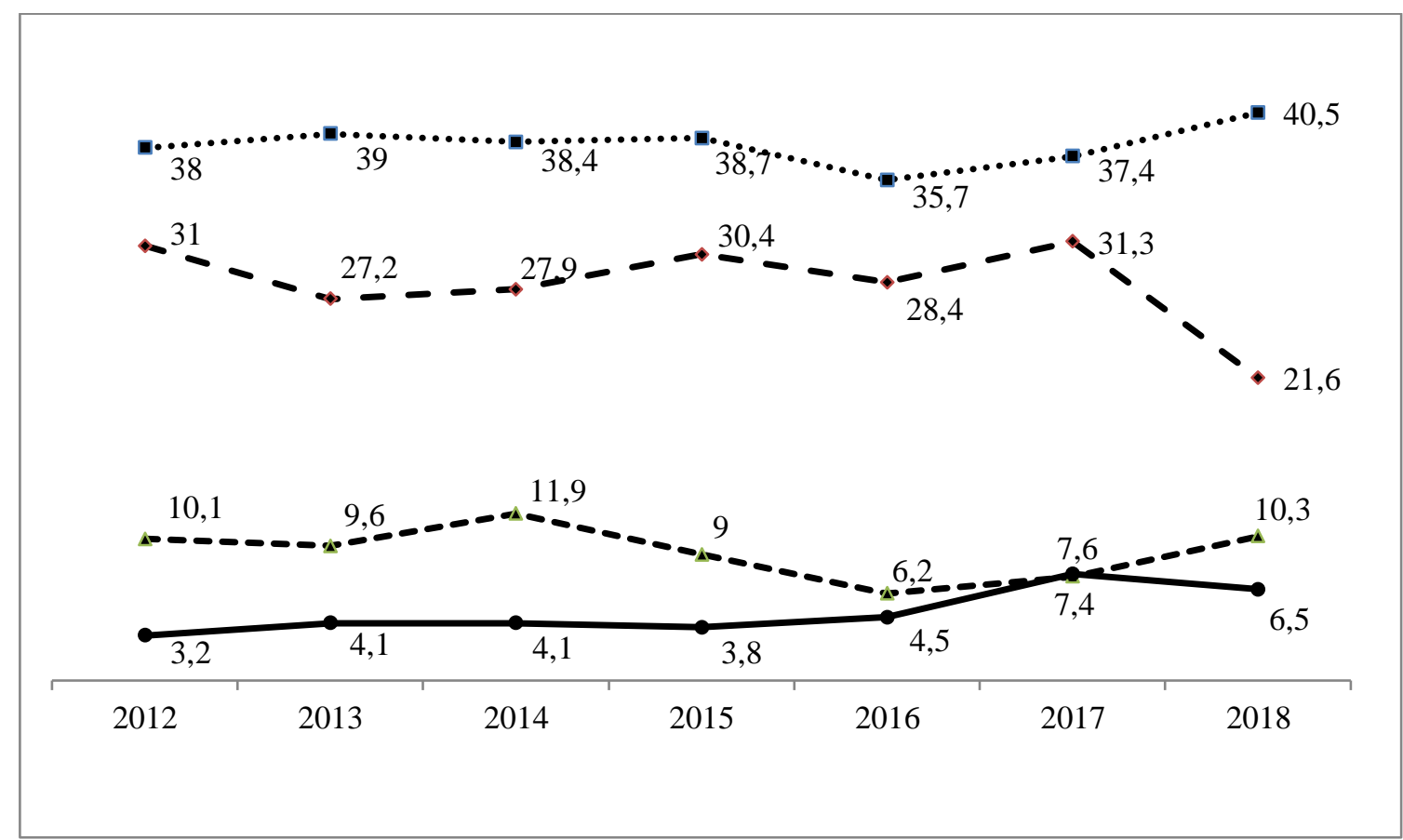

Growth rates of food production in the period 2008-2017 remained stable at $14.1 \%$, while the share of the region in the volume of industrial output was 38\%. Meanwhile, food production in 2018 fell by 2.7 percent compared to 2017. The slowdown in food industry production in 2018 was due to a decrease in vegetable oil production (crude oil production decreased by $7.7 \%$, refined oil by $12.5 \%$ ), and vodka (by $16 \%$ ). In the structure of enterprises, production decreased by $6.9 \%$ at JSC "Namanganvino", by $3.8 \%$ in the joint venture "Nestle-Uzbekistan" and by $0.2 \%$ in the JSC "Uchkurgan grain products".

The diversification processes in the industry have declined from $39 \%$ in 2013 to $35.7 \%$ or $8.5 \%$ in 2018 due to raw material shortages as well as institutional reforms in recent years.

Fig 2

Share of the food industry of Namangan region in the gross industry and GDP

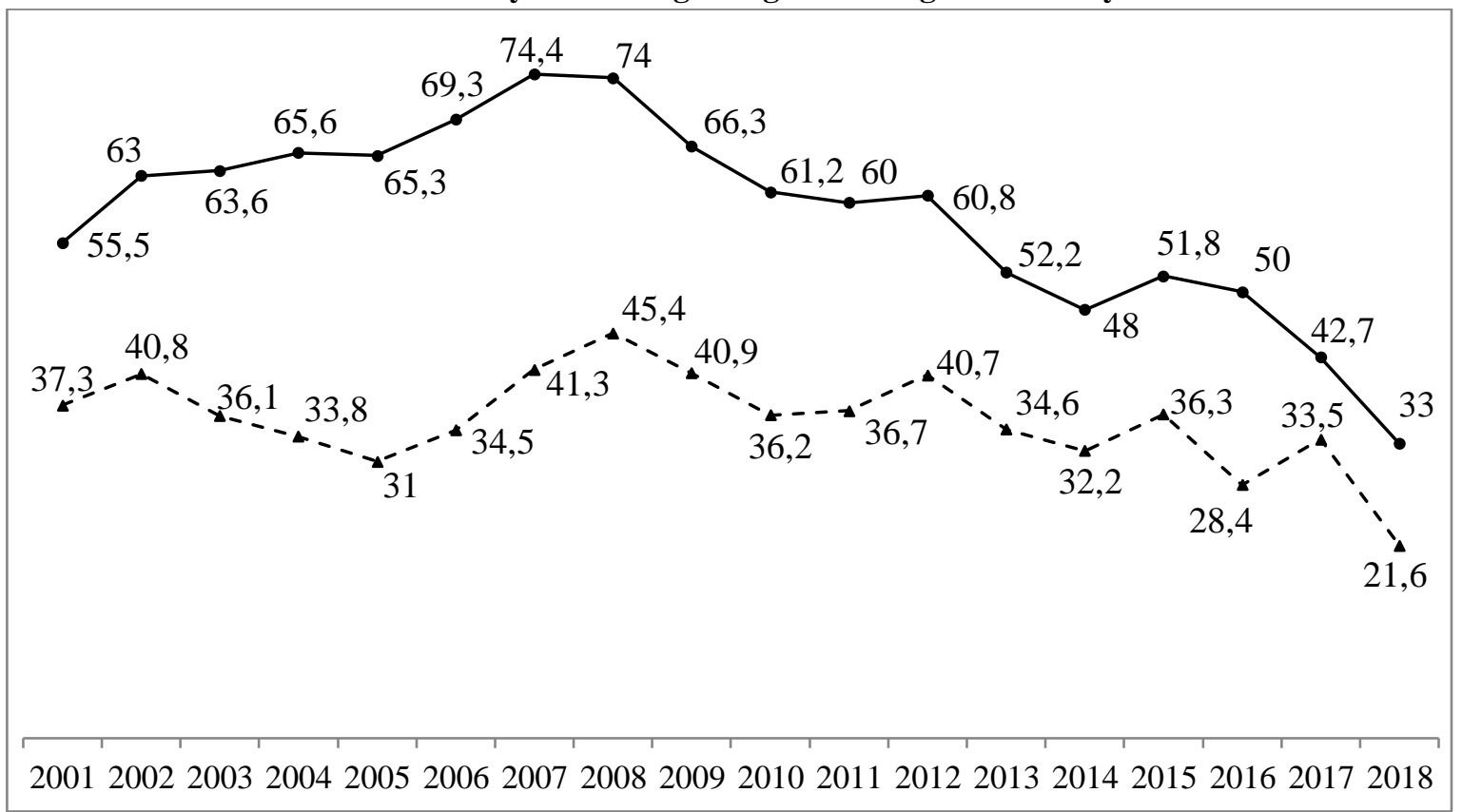

The food industry, despite being the second largest in the gross output of the industry after light industry (38.5\% for 2001-2018), has more than doubled its growth rate. 
If the focus is on the analysis of Figure 2.6 above, the share of the food industry in the production of gross industrial products and consumer goods can be divided into two periods. In particular, the period from 2008 to 2008 was characterized by a rapid increase in the share of the sector, and accordingly, the gap between the share of the industry and consumer goods tended to grow. Thus, the share of food industry in the gross regional industrial production increased from $35.8 \%$ in $2001-2005$ to $40.4 \%$ in $2006-2008$, or increased by almost 5 points. This is primarily due to large-scale localization in the early 2000s, modernization of industrial enterprises, broad activities of joint ventures and small business and private entrepreneurship, and, secondly, industries such as chemical, machine-building and metalworking, building materials. tendency to decline in the activity of enterprises.

Period 2 - post-2008, during which time the share of the industry tended to decrease, especially in the structure of consumer goods. This can be explained by the large-scale modernization, diversification of industrial production observed in the region since 2009, including increasing the volume and range of consumer goods on the basis of increasing the mobilization of local resources into the economy and the implementation of regional state programs.

A more in-depth look at the food industry in this case study can be attributed to:

First, the peculiarities of the territorial structure of industrial production in the Namangan region. The share of industrial production in Namangan was $47.1 \%, 9.7 \%$ in Namangan region, $8.7 \%(14.1 \%)$ in Uchkurgan district, $8.5 \%(5.5 \%)$ in Turakurgan, $7.1 \%$ in Uychi, $4.8 \%$ in Uzbekistan. The area of Pop district. The lowest polarity is in the districts of Yangikurgan (1.2\%), Chortoq (1.7\%), Mingbulak (2.3\%), except for Namangan, where the polarity is 8.1 times. Despite the traditional "polarization" of industrial production by regional structures, the share of Uchkurgan district, which is the industry's "pole", dropped by $8.7 \%$ or 1.6 times from $14.1 \%$ in 2017 to Namangan district. and released him. The share of Turakurgan district, which currently occupies $5.5 \%$ of the regional industry in 2017 , increased by $8.5 \%$ in 2018 , or increased 1.5 times.

Currently, the total number of industrial enterprises in Uchkurgan district is 94, in Turakurgan 130, in Chust - 159, and in Kosonsay district - 169. It is noteworthy that there are 3 large industrial enterprises in each of the districts in this sample. Clearly, the volume of industrial production is primarily related to the sectoral specialization, not the number of enterprises in territorial units. In Kosonsoy 13.9\%, Turakurgan $12.4 \%$, Chust $20.2 \%$, Uchkurgan $60.2 \%$ industrial products.

Secondly, the degree of localization of industrial enterprises operating in the region. This indicator, first of all, is characterized by the development of raw materials, resource base of the food industry, production capacity, and quality of labor resources. Namangan region has a total of 390,400 hectares of agricultural land, including 152,600 hectares of pastures and 199,000 hectares of irrigated land. The total area of gardens is 21.9 thousand hectares. The volume of gross agricultural output made up 13320,5 bln. soums (2018), with an average annual growth of 5.7-6\% over the last 10 years, but decreased by $0.5 \%$ in 2018. Decrease in gross output of the sector was due to the decrease in production of cereals $(14.9 \%)$, potatoes $(7.0 \%)$, vegetables $(2.1 \%)$, grapes $(8.9 \%)$.

The share of livestock in the gross agricultural sector was $39.5 \%$, which is 1.4 points higher than in the previous year. This is due to a decrease in the production of basic agricultural products, as seen above. The average yield is $50.3 \mathrm{c} /$ ha, potatoes $-177.4 \mathrm{c} /$ ha, vegetables $-228.5 \mathrm{c} / \mathrm{ha}$, melons $-204 \mathrm{c} / \mathrm{ha}$, fruit - $59.4 \mathrm{c} /$ ha. , $5 \mathrm{t} / \mathrm{ha}$.

Transformation of the Namangan Engineering and Economic Institute into the Namangan Engineering and Technology Institute from 2011 on the basis of the government resolution creates additional conditions for the formation of a qualified labor force in the field of food technology.

Thirdly, the degree to which industrial enterprises are provided with consumer markets. As you know, the main part of the food industry is households. At present, there are 2699.0 thousand people living in 514 settlements of Namangan region. This represents $8.3 \%$ of the country's population. Unlike other regions of Uzbekistan, the level of supply of food industry enterprises with consumer markets is significant, given the interconnectedness of the provinces and districts in the Fergana region, the density of the population, and the proximity of the Tashkent region, which is a kind of "pole" in the consumer market. positive character.

Fourth, the potential of the food industry in the region's export potential. As of 2017, the region's total exports are expected to be 196.7 million, and in 2018 - 237.6 million. Or increased by $20.8 \%$. At the 
same time, the share of exported foodstuffs in the region fell from $37.3 \%$ in 2017 to $33.0 \%$ in 2018 , or decreased by $11.5 \%$. However, it should be noted that the share of this sector in the structure of imported goods in the region decreased from $12.9 \%$ in 2017 to $6.8 \%$ or almost 1.9 times.

\section{CONCLUSION AND RECOMMENDATIONS}

These considerations not only show the prospects for the development of the food industry within the Namangan region's industrial complex, but also indicate the need for regional restructuring. Restructuring of any scale is a set of measures for optimal systemic change in order to adapt the structure of economic activity (assets, property, finance, management, staff, etc.) to the ever-changing internal and external environment. Restructuring should be aimed at ensuring the "strategic stability" of economic entities. This is the ability to create, develop and maintain a long-term competitive advantage of an economic entity in the segmented goods market. As a result, their liquidity, solvency and profitability are maintained. Regional restructuring requires the use of regional restructuring resources and a system of mechanisms differentiated by investment and entrepreneurial activities. This approach creates conditions for identifying, activating growth points in the regions and creating new opportunities systems. Natural and climatic and resource potential of the regions, specialization directions, level of social and economic development, condition of infrastructure development, innovation-investment and entrepreneurial activity of the economic system influence the processes of restructuring in the region. In this context, any restructuring is of a regional nature.

\section{REFERENCES}

1. Nagoyeva A.K. Restructuring of the regional economic system as a way out of a depressed state. Maykop, Bulletin of the Adygea State University, 2011. No. 2.

2. Gerhard P. Andersen R. et al. Privatization and restructuring of industrial enterprises in Central and Eastern Europe. Washington. The World Bank. 1998 .;

3. Vodachek L. Restructuring - a challenge to Czech enterprises. // Problems of theory and practice of management. - 1999. No. 1;

4. Alpatov A. Restructuring of enterprises: mechanisms and organizational measures. //Economist.2000. -No.3.-S.26-35; Bachurin A.Restructuring and reforming of production. //Economist. - 1999. No.9. - S.23-29;

5. Miscavige V. Restructuring of a large enterprise: experience, problems, assessments. // Economics and life - 1999. - No. 33. - S.26-35 ; Tutunjyan A. Restructuring of an enterprise. //Marketing. - 2002. - No. 2. - S.88-101;

6. Mazur I.I., Shapiro V.D. "Restructuring of enterprises and companies." Moscow 2001; Ekimova N. Formation of the regional policy of restructuring the public sector of the economy. Abstract of dissertation for the degree of candidate of economic sciences. - Moscow - 2006 ;;

7. Nagoyeva A.K. Restructuring of the regional economic system as a way out of a depressed state. Maykop, Bulletin of the Adygea State University, 2011. No. 2.

8. Saidova G.K. Status and objectives of the further development of post-privatization support processes and enterprise restructuring. // Materials of the Republican scientific and practical seminar (August 23, 2002 Tashkent.). - S. 6-8 ;

9. Abdullaeva M.N. The effectiveness of strategic planning at industrial enterprises of the Republic of Uzbekistan (for example, the Uzmetkombinat APO) Abstract. diss. for a job. uch step. candidate of economic sciences. T., 2006;

10. Berkinov B.B. Status and objectives of the further development of post-privatization support processes and enterprise restructuring. // Materials of the Republican scientific and practical seminar (August 23, 2002 Tashkent.). - S. 27-32 ;;

11. Berdiqulov A. Restructuring of enterprises of the building materials industry in the conditions of modernization of the economy of Uzbekistan (on the example of the Jizzakh region). Abstract. diss. for a job. uch step. candidate of economic sciences. T., 2011.

12. Gurkov I., Avraamova E. Strategy for the survival of industrial enterprises in the new conditions // Issues of Economics. - 1995.№ 6.S. 22-Gurkov, I.B. Strategic management of the organization: Textbook. The allowance / I.B. Gurkov. - 2nd ed., Rev. and add. - M.: TEIS, 2004 .-- 239 p.

13. Gutnin V.P. Household policy in Germany. - M .: CJSC Publishing House Economics, 2002.

14. Smooth Yu.N., Chistobaev A.I. Fundamentals of Regional Policy: A Textbook. -SPb .: Publishing House of Mikhailov V.A. 1998.659p.

15. Nagoyeva A.K. Restructuring of the regional economic system as a way out of a depressed state. Matola Magazine "Securities Market" №23 2000. 